\title{
Depositional Environments and Reservoir Evaluation of Otuma Oil Field, Niger - Delta basin, Nigeria
}

\author{
Godwin O. Aigbadon, Goriola O. Babatunde, Mu'awiya B. Aminu, \\ Changde A. Nanfa, and Simon D. Christopher
}

\section{ABSTRACT}

This study was carried out by using well logs to evaluate the depositional environments and hydrocarbon reservoirs in the Otuma oil field, Niger Delta basin. The gamma motif/model within- study interval in the drilled well shows blocky, symmetrical, and serrated shapes which suggest a deltaic front with mouth bar to a regressive - transgressive shoreface delta respectively. A correlation was done on the well logs across the wells and the ten well logs were used to evaluate the petrophysical characteristics of the reservoirs. The reservoirs showed highly porous and permeable channels where the wells were used for the characterization. The ten reservoirs were mapped at a depth range of $2395 \mathrm{~m}$ to $2919 \mathrm{~m}$ with thicknesses varying from $4 \mathrm{~m}$ to $135 \mathrm{~m}$. The petrophysical results of the field showed that the porosity of the reservoirs ranges between 0.10 to 0.30 , and permeability from $48 \mathrm{md}$ to $290 \mathrm{md}$; the water saturation ranges from 0.39 to 0.52 , and hydrocarbon saturation from the field 0.48 to 0.61 . The Bypassed hydrocarbons identified in low resistivity pay sands D4 and D3 at depth $2649 \mathrm{~m}$ to $2919 \mathrm{~m}$, respectively were also evaluated and will be put to production in the field.

Keywords: Depositional environments, log data, Otuma oil wells, reservoirs.
Published Online: December 29, 2021

ISSN: $2684-446 \mathrm{X}$

DOI :10.24018/ejgeo.2021.2.6.233

\section{G. O. Aigbadon*}

Department of Geology, Faculty of Sciences, Federal University Lokoja, Kogi State, Nigeria.

(e-mail:

godwin.aigbadon@fulokoja.edu.ng)

G. O. Babatunde

Wesley University, Ondo, Nigeria.

M. B. Aminu

Department of Geology, Faculty of

Sciences, Federal University Lokoja,

Kogi State, Nigeria.

(e-mail:

muawiya.babaaminu@fulokoja.edu.ng)

C. A. Nanfa

Department of Geology, Faculty of Sciences, Federal University Lokoja, Kogi State, Nigeria.

(e-mail: nanfa.changde@fulokoja.edu.ng) C. S. Dalom

Department of Geology, Faculty of Sciences, Federal University Lokoja, Kogi State, Nigeria.

(e-mail:

simon.christopher@fulokoja.edu.ng)

*Corresponding Author

\section{INTRODUCTION}

This research paper is established on a detailed evaluation of the Otuma oil field, Niger delta Basin. The study is to reevaluate the reservoir heterogeneity, their characteristics as well as the depositional environments. Niger Delta basin and its hydrocarbon resources have been discussed by [2]-[6] However, detailed study has not been carried out in the Otuma oil field. There is high demand for hydrocarbon for both domestic and industrial uses with a low rate of production. There is a need to increase the country's hydrocarbon reserve base to over 40, 000bbls of oil. The main aim of this research is to carried-out the detailed correlation on the reservoir units across the wells, detailed description, and petrophysical evaluation of the reservoirs to ascertain the reservoir performance. Also, to evaluate reservoir characteristics from facies distribution and depositional environments of the wells in the Otuma oil field. This will give an enhanced understanding of the depositional environment, facies, reservoir heterogeneity, and its quality.

\section{STUDY LOCATION}

The Otuma field is located northwest of the Niger Delta with Latitude $5^{\circ} 32^{\prime} \mathrm{N}$ and Longitude $7^{\circ} 9^{\prime} \mathrm{E}$. Niger Delta is one of the world's major hydrocarbon provinces and it is situated on the Gulf of Guinea on the west coast of central Africa (Southern Nigeria; Fig.1 \& 2).

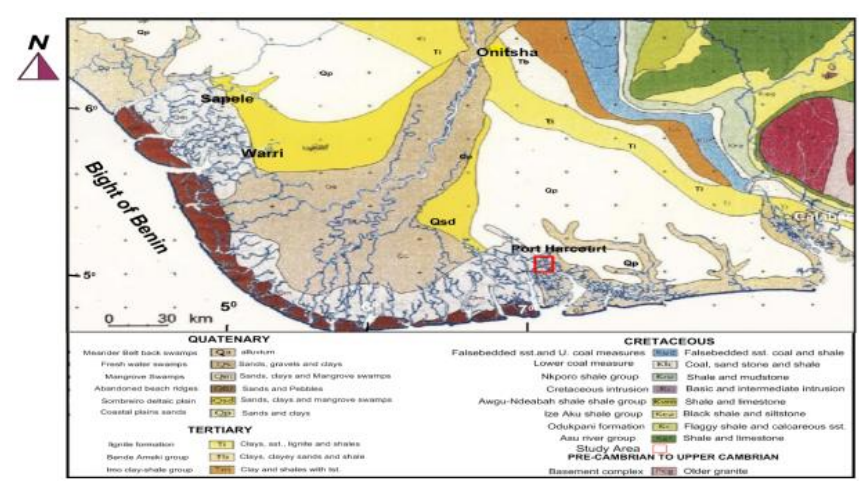

Fig. 1. Geological map of the Niger Delta showing study location (Modified After [1]). 


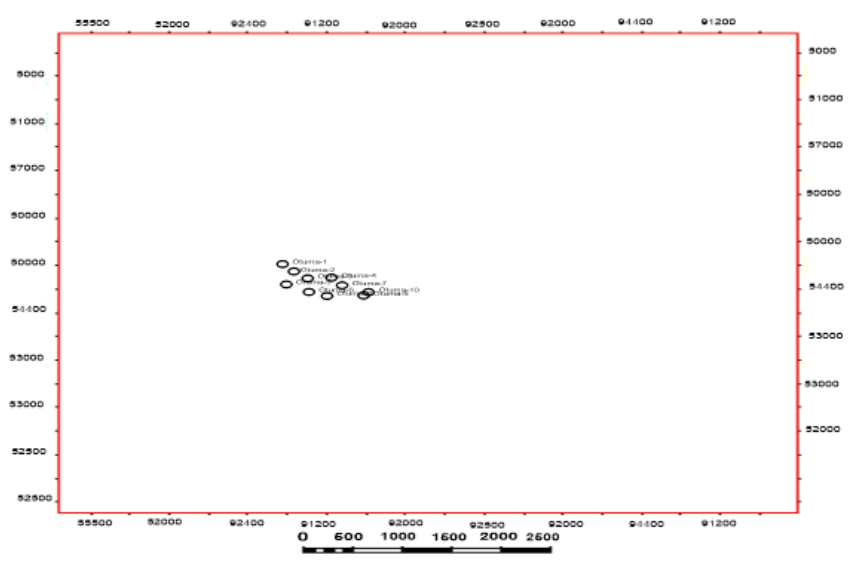

Fig. 2. Well location map of the study area.

\section{A. Lithostratigraphic Units of the Niger Delta Basin}

Three major lithostratigraphic units have been recognized in the Niger Delta basin and discussed in [1], [3], [7], [8]. They are Akata, Agbada, and Benin Formations ranging from the oldest to youngest.

\section{B. The Akata Formation}

The Akata Formation (Paleocene - Recent) represents the marine prodelta facies. It is composed of thick shale sequences (potential source rock) and minor amounts of clay and silt. The Akata Formation was deposited during low stands tract. It contains terrestrial organic matter and clays sediments. Its estimated thickness is about 7,000 meters [8]. The formation underlies the entire delta, and it is characterized by over- pressure shales.

\section{The Agbada Formation}

The deposition of the underlying Agbada Formation was during the Eocene. The Agbada Formation consists of sandstone, alternation of sand-shale units in the delta. The sandstone units are major petroleum-bearing units that house the hydrocarbon. The formation has a thickness of about 4000 meters and represents the true deltaic portion of the sequence. Agbada Formation is also called the parallic Agbada Formation because the shale and sandstone beds were deposited in equal proportions. Though, the upper part is mainly characterized by sand with minor shale interbeds.

\section{The Benin Formation}

The Benin Formations (Oligocene-Recent) is about 2000 meters in thickness, but up to 2,100 meters in the region of maximum thickness [8]-[9], and they are mainly of continental sands and lack micro-faunas (Fig. 3).

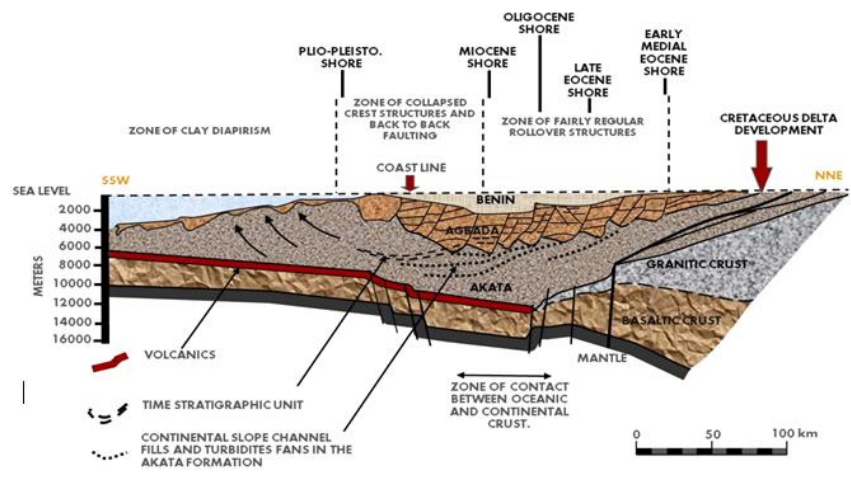

Fig. 3. Generalized Dip section of the Niger Delta Basin [8], [5], [6].

\section{MATERIALS AND METHODS}

The data for this research consists of suites of well logs from ten different wells in the field (Table I).

\section{A. Methodology}

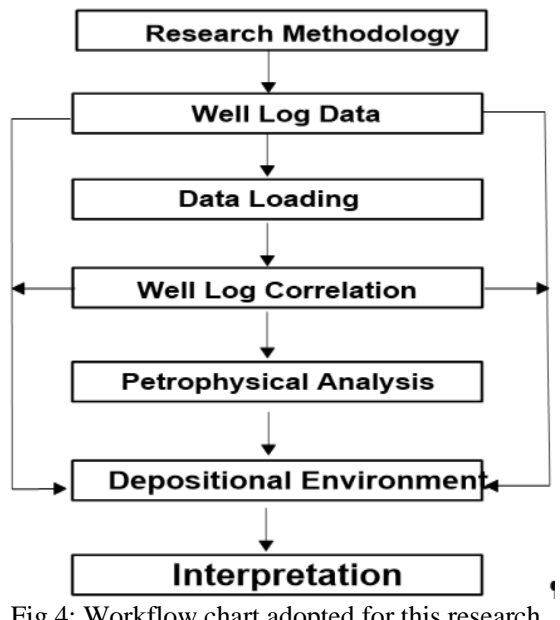

The method adopted for the research shown in (Fig. 4). The method of analysis involved delineation of rock types, identifying rocks, and correlation of rock types by $\log$ signatures across the ten wells. The well logs signatures/ motifs were used for the identification of the paleoenvironments (environment of deposition) based on the $\log$ motifs according to [10].

For the petrophysical analysis, a quality check was carried- out on the well logs data across the eleven wells to avoid pitfalls in their interpretation before being imported into Geolog for Petrophysical Interpretation. On average the well logs was fair. The following equations 1-9 were used for the petrophysical evaluations in the wells below:

TABLE I: SUMMARY OF THE FIELD WELL LOGS

\begin{tabular}{cccccccc}
\hline \hline Well Name & Well Header & Check shot & Deviation Data & Gamma Ray Log & Resistivity Log & Neutron Log & Density Log \\
\hline Well 1 & - & - & - & X & X & X \\
Well 2 & - & - & - & X & X & X \\
Well 3 & - & - & - & X & X & X \\
Well 4 & X & X & X & X & X & X \\
Well 5 & - & - & - & X & X & X \\
Well 6 & - & - & - & X & X & X \\
Well 7 & - & - & - & X & X & X \\
Well 8 & - & - & - & X & X & X \\
Well 9 & - & - & - & X & X & X \\
Well 10 & - & - & & X \\
Well 11 & - & &
\end{tabular}




$$
I_{G R}=\frac{\left(G R_{\log }-G R_{\min }\right)}{\left(G R_{\max }-G R_{\min }\right)}
$$

where IGR = Gamma-Ray index; $\mathrm{GR}_{\log }=$ Gamma-Ray reading of the formation; $\mathrm{GR}_{\min }=$ minimum Gamma-Ray reading (sand baseline), $\mathrm{GR}_{\max }=$ maximum Gamma-Ray reading (shale baseline):

$$
\begin{aligned}
V_{s h} & =0.083\left(23.7 \times I_{G R}-1\right) \\
\phi_{T} & =\frac{\left(\rho_{m a}-\rho_{b}\right)}{\left(\rho_{m a}-\rho_{f}\right)}
\end{aligned}
$$

where $\rho_{\mathrm{ma}}=$ matrix density which is taken to be $2.65 \mathrm{~g} /$

For sandstone, $\rho_{b}=$ the bulk density read directly from the $\log , \rho_{\mathrm{f}}=$ the fluid density which is taken to be 1 for gas and 0.87 for oil.

$$
\begin{aligned}
& \phi_{\text {eff }}=\varphi_{\text {total }}-\left(\phi_{\text {sh }} \times V_{\text {sh }}\right) \\
& N T G=\frac{\text { Net sand }}{\text { Gross sand }}
\end{aligned}
$$

Net sand $=$ Gross sand - Shalyint ervals (6) [11]

$$
K(m D)=\frac{0.136 \varphi^{4.4}}{\text { Swirr }^{2}}
$$

where $\mathrm{K}(\mathrm{mD})=$ Permeability in milli-Darcy, $\Phi=$ porosity, $S_{\text {wirr }}=$ Irreducible water saturation.

$$
\begin{aligned}
& S_{w}=\left[\left(\frac{a \times R_{w}}{R_{t} * \varphi_{e}^{m}}\right)^{\frac{1}{n}}\right] \\
& S_{h}=1-S_{w}
\end{aligned}
$$

Where $S_{w}=$ water saturation; $R_{w}=$ resistivity of water (that is resistivity of formation water); $R_{t}=$ true formation resistivity derived from the deep induction resistivity log; $\Phi$ $=$ porosity, $\mathrm{n}=$ saturation exponent usually taken as $2.0 ; \mathrm{m}=$ cementation factor; $\mathrm{a}=$ tortuosity.

\section{RESULTS AND DISCUSSION}

\section{A. Correlation in the Wells}

The well correlation panel shows the tops and bases of the reservoirs A, B, C, D1 and D2 in wells 1-10 range from (2395-4530 m), respectively in Otuma oil wells. The GR log motifs show that the overall lithology is an alternating sequence of sands and shales Otuma oil wells 1-10 (Fig. 5).

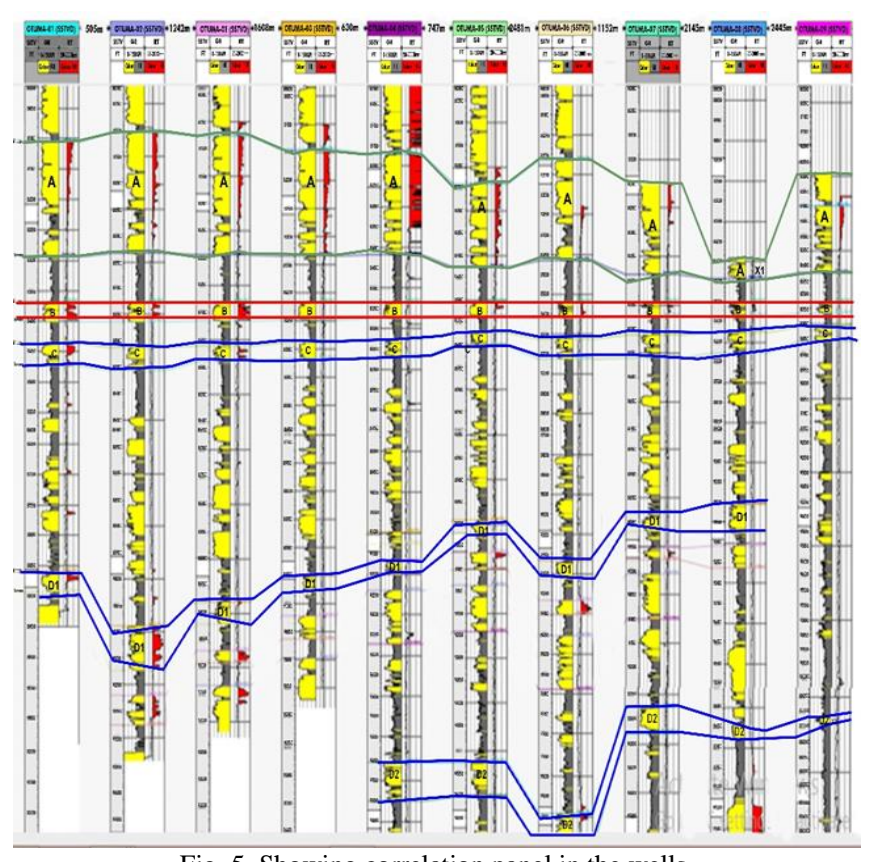

Fig. 5. Showing correlation panel in the wells.

The correlation reveals that and $\mathrm{X} 1$ and $\mathrm{X} 2$ exist as separate sand bodies due to faulting (Fig. 5). The shale beds increase with depth along with a corresponding decrease in sand layers. This is a typical pattern in the Niger Delta which shows the transition from Agbada Formation to Akata Formation.

\section{B. Depositional Environment and Lithofacies from Gamma-ray Log Motif \\ 1) Log Facies and Depositional Environment for wells 1-10}

The studied reservoir interval 8000-9750 ft (2395-530 m) in the wells (Fig. 5) shows that the GR log motif depicts a blocky car box trend (reservoirs A and B in wells 1-10 and reservoir $C$ in wells 1-6, and10), symmetrical model (reservoirs C in wells 7, 8, and 9; D1 in wells 1, 2, and 9) and serrated models (reservoirs D2 in wells 5-10) [10], [13]. From the integrated data set of GR $\log$ and Resistivity $\log /$ Electorofacies logs, four depositional facies were recognized as channel sands (reservoirs A, B in the ten wells), tidal and distributaries channels sands (reservoirs $\mathrm{B}, \mathrm{C}$ in the ten wells), and fluvial flood plains (D1, D2). The GR log motifs show the lithology characteristics are alternating sequences of sand shale. The prominent sequence in the wells located in the channels comprises the reservoir rocks with intercalation of sand and shale bodies depicting that logging begins at the basal part of the Benin Formation down to the Agbada Formation (Fig. 5). The depositional environment of the studied well intervals can be conveniently classified as a deltaic-fluvial environment based on the $\log$ motif and depositional facies models [10], [13]; (Fig.6). This stratigraphic sequence is a common feature of the Agbada Formation in the Niger Delta, where these channels serve as reservoirs in the field. These reservoirs are the productive zone based on the Wire line log motif and the depositional models for the field. (Fig. $5 \& 6$ ). 


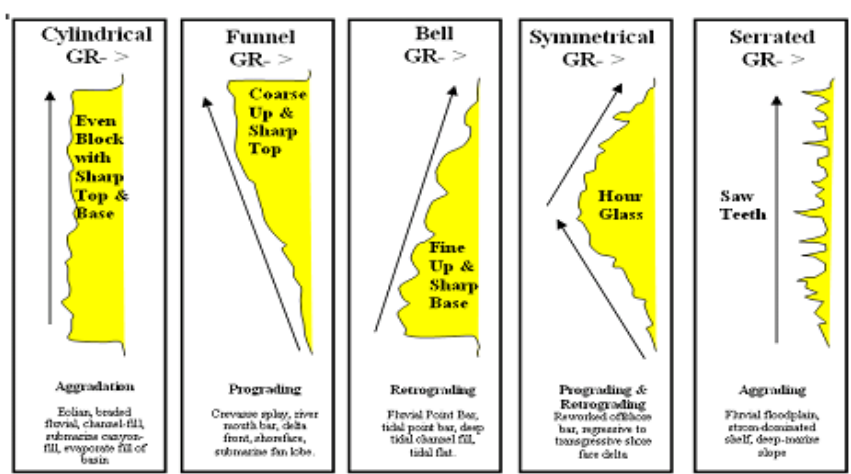

Fig. 6. Direct correlation between facies and a variety of other log shapes relating to Sedimentological relationship by Cant [10].

\section{Petrophysical analysis results for Otuma oil field}

The effective porosity of $0.10-0.30$, NTG of $0.49-0.87$, the permeability of 48-290 md for reservoirs A, B, C, D1, and D2 which contains the producible amount of hydrocarbon in the wells have cut off from Very good to poor. There is also a good pore throat communication network from wells 1-7 until faulting occurs at well 9 (X1) (Fig. 5). The effective porosity values range from $0.10-0.30$ in the wells after correction for shale effects is done on the reservoir to improve the quality. The porosities cut-off is fair enough to support hydrocarbon production and exploitation in the wells [14]. The shale content estimated at reservoirs A, B, C, and D1, D2 (bypassed zone reservoirs) ranges $0.16-0.24$ as such will not hinder production in the field.

Water saturation $\left(S_{\mathrm{w}}\right)$ of $0.39-0.52$ in reservoirs $A, B, D 1$, and D2 in the wells. The calculated water saturation in the wells is not too much that it will affect hydrocarbon production in the field. Though bypassed reservoir D2 will be produced hydrocarbon alongside water. The amount of hydrocarbon saturation in the well's ranges from $0.48-0.61$. The calculated hydrocarbon saturation for the bypassed reservoirs D1, D2 on average is 0.49 . Though reservoir D2 will produce hydrocarbon alongside with water due to high water saturation of 0.52 .

\section{CONCLUSIONS}

This research was able to evaluate depositional environments, predict reservoir performance and improve reservoir quality at mapped horizons in the wells from the field by using well log data. The well log data analyses were used to interpret and reconstruct the environment of deposition in the field. The well log motif depicts a deltaicfluvial environment. The petrophysical analysis used to characterize the reservoirs in terms of porosity, permeability, and reservoir architecture units. From the petrophysical results, the porosity, NTG, permeability cutoff is poor to very good. The water saturation values in the wells are not relatively too high in wells $\mathrm{A}, \mathrm{B}$, and $\mathrm{C}$ indicating that major reservoirs $\mathrm{A}, \mathrm{B}, \mathrm{C}$ will produce hydrocarbon without water.

\section{RECOMMENDATIONS}

I recommend integration of well $\operatorname{logs}$, core data, seismic data and a 4-D Study to identify new prospects in the study area.

\section{ACKNOWLEDGMENT}

I acknowledged Shell Petroleum Development Company (SPDC), Port Harcourt by the Permission of Department of Petroleum Resources (DPR), Nigeria for making available the data for this research. I also acknowledge Wesley University Ondo for using their workstation and space provided for the research.

\section{FUNDING}

No funding of any form was received for this research.

\section{CONFLICT OF INTEREST}

The authors have no conflicts of interests to make known.

TABLE II: PETROPHYSICAL RESULTS OF THE RESERVOIR IN THE FIELD

\begin{tabular}{|c|c|c|c|c|c|c|c|c|}
\hline $\begin{array}{l}\text { Reservoirs } \\
\text { Depth (m) }\end{array}$ & $\begin{array}{l}\text { Reservoirs } \\
\text { Name }\end{array}$ & Thickness(m) & NTG & $\mathrm{V}_{\mathrm{sh}}$ & $\phi_{e f f}$ & $\mathrm{~K}(\mathrm{md})$ & $S_{w}$ & $\mathrm{~S}_{\mathrm{h}}$ \\
\hline $\begin{array}{l}2395- \\
2530\end{array}$ & A & 135 & 0.87 & 0.16 & 0.30 & 290 & 0.39 & 0.61 \\
\hline $\begin{array}{l}2501- \\
2514\end{array}$ & B & 13 & 0.67 & 0.18 & 0.20 & 162 & 0.43 & 0.57 \\
\hline $\begin{array}{l}2529- \\
2537\end{array}$ & $\mathrm{C}$ & 8 & 0.57 & 0.20 & 0.15 & 100 & 0.48 & 0.52 \\
\hline $\begin{array}{c}2649- \\
2653\end{array}$ & D1 & 5 & 0.50 & 0.22 & 0.12 & 50 & 0.49 .5 & 0.50 \\
\hline $\begin{array}{l}2915- \\
2919\end{array}$ & D2 & 4 & 0.49 & 0.24 & 0.10 & 48 & 0.52 & 0.48 \\
\hline
\end{tabular}

\section{REFERENCES}

[1] Reijers TJA. Stratigraphy and sedimentology of the Niger Delta. Geologos, 2011;17 (3): 133-162, doi: 10.2478/v10118-011-0008-3

[2] Merki PI. Structural Geology of Cenozoic Niger Delta. First African Regional Geological Conferences 1970; Ibadan University Press, Ibadan, Nigeria, 1972, pp. 251-266.

[3] Weber KJ, Daukoru EM. Petroleum geology of Niger Delta. $9^{\text {th }}$ World Petroleum Congress, 1975 (2): 209-221.

[4] Lambert-Alkhionbare DO. The Agbada shales as source rocks for the Niger Delta Petroleum. Abstract of proceedings $10^{\text {th }}$ Annual
Conference. Nigerian Mining and Geoscience Society, Lagos, 1981, pp.180- 202.

[5] Aigbadon GO, Akpunonu, EO, Agunloye SO, Ocheli A, Akakaru, CO. Depositional Environment and facies analysis of Useni-1, Niger Delta Basin, using well logs, core data. International Journal of Advanced Geosciences, 2019; 7 (1): 58-66.

[6] Aigbadon GO, Okoro AU, Una CO, Ocheli A. Depositional facies model and reservoir Characterization of Usani field 1, Niger delta basin, Nigeria. International Journal of Advanced Geosciences, 2017; 5 (2): 57-68. 
[7] Short KC and Stauble AJ. Outline of geology of Niger Delta. Association of American Petroleum Geologist Bulletin, 1967; (51): 761-779.

[8] Doust H, Omatsola ME. Divergent passive margin basins. Association of American Petroleum Geologist Memoir, (1990); (48): 201-238.

[9] Whiteman AJ. Nigeria: It petroleum geology, resources and potential. London, Graham and Trothman, 1982; 1:166.

[10] Cant DJ. Subsurface facies analysis. Facies models: Response to sea level change. Geological Association of Canada. ISBN:0919216498, 409: 1992.

[11] Schlumberger Log interpretation principles / application/charts. Exploration and Production (E \& P) Technical Journal of Middle East, 2013; (9): 1-140.

[12] Schlumberger Log Interpretation, Principles and Application: Schlumberger Wireline and Testing, Houston, Texas, United State of American, 1989, pp.21-89.

[13] Bush DA. Influence of growth fault on sedimentation and prospect evaluation. The Association of American Petroleum Geologist Bulletin, 1985, 3 (59): 414-419.

[14] David DK. Foundation of petrophysics manual Petro skills training manual, Oklahoma, USA, 2002, (B): 104. 